\title{
Academic Application Design WEB-based on junior high schools
}

\author{
Baenil Huda ${ }^{1}$ \\ Information Systems Study Program \\ School of Engineering and Computer Science \\ Universitas Buana Perjuangan Karawang \\ baenilhuda@ubpkarawang.ac.id
}

\author{
Fitri Nurapriani $^{2}$ \\ Information Systems Study Program \\ School of Engineering and Computer Science \\ Universitas Buana Perjuangan Karawang \\ fitri.apriani@ubpkarawang.ac.id
}

\author{
Helga Amanda ${ }^{3}$ \\ Information Systems Study Program \\ School of Engineering and Computer Science \\ Universitas Buana Perjuangan Karawang \\ si15.helgaamanda@mhs.ubpkarawang.ac.id
}

\begin{abstract}
Current advances in information technology have provided great benefits in the world of education, making webbased academic applications is a major use of information technology. Information technology enables academic data to be processed and, making the required presentation of academic information be got, and. This research uses technological trends in managing academic administration so that conventional bookkeeping in junior high schools is overcome by computer systems. The method in developing the system uses a waterfall with WEB-based device implementation. The application of this new system can improve the knowledge and skills of employees, teachers, and principals in web-based academic applications.
\end{abstract}

Keywords-Application, Academic, Web Based, Waterfall.

\section{INTRODUCTION}

The development of information technology requires accuracy in data processing for all institutions or institutions. The more precise in data processing, the easier it will be to get the trust of consumers, so that each institution or institution uses a structured information system that can answer and process data, including School Academic data processing.

Using information in schools, besides improving quality, will also facilitate the administration such as business governance of existing data such as student data, teacher data, class data, student learning outcomes data, and subjects. Data management like this will be easier and more effective by using academic information systems.

junior high schools one Purwasari in processing academic data processing student data, teacher data, lesson schedules, and others are still using a manual system. With a total class of 27 classes, comprising class VII (9 classes), VIII ( 8 classes), IX (8 classes). The number of students in each class is almost 40 students and the number of teachers is almost 30 , so it is very inefficient in processing academic data.

By looking at the fun - challenging in junior high schools one Purwasari, the author wants to create an academic information system and take the title "Web-Based Academic Application Design at junior high schools one Purwasari".

\section{THEORETICAL BASIS}

\section{A. Design}

The design is a visual form that results from the planned creative forms. Design is the process of planning everything [1]. System design is a phase in which design expertise is needed for computer elements that will use the system, namely the selection of equipment and computer programs for the new system [2].

\section{B. Application}

Application is a ready-made program that can run commands from the user of the application to get more accurate results following the purpose of making the application. Application is a problem solving that uses one of the application data processing techniques which refers to a desired or expected computation or expected data processing [3].

\section{Academic}

Academics are a condition where people can convey and accept ideas, thoughts, science, and be able to test them [4], The word academic comes from the Greek academic which means a public park (plasma) in the northwest of Athens. After that, the word academic turned into academic, which is a kind of college place [5].

\section{Website}

A website is a collection of pages where a page is linked to other pages [6]. Website is a collection of web pages that are interconnected and it relates the files to one another [7].

\section{RESEARCH METHODS}

In this study refers to the waterfall model. At each stage in this study does not always depend on the user, only an analysis phase is a step approach to the user. Therefore, in developing the software, researchers used the waterfall method.

\section{RESULT AND DISCUSSION}

\section{A. Analysis of the current system}

The process of data processing and academic information storage at junior high scholes one Purwasari Karawang still uses a manual system, it requires quite a long time to make the process of reporting information. The following is a flow map system that runs in data processing: 


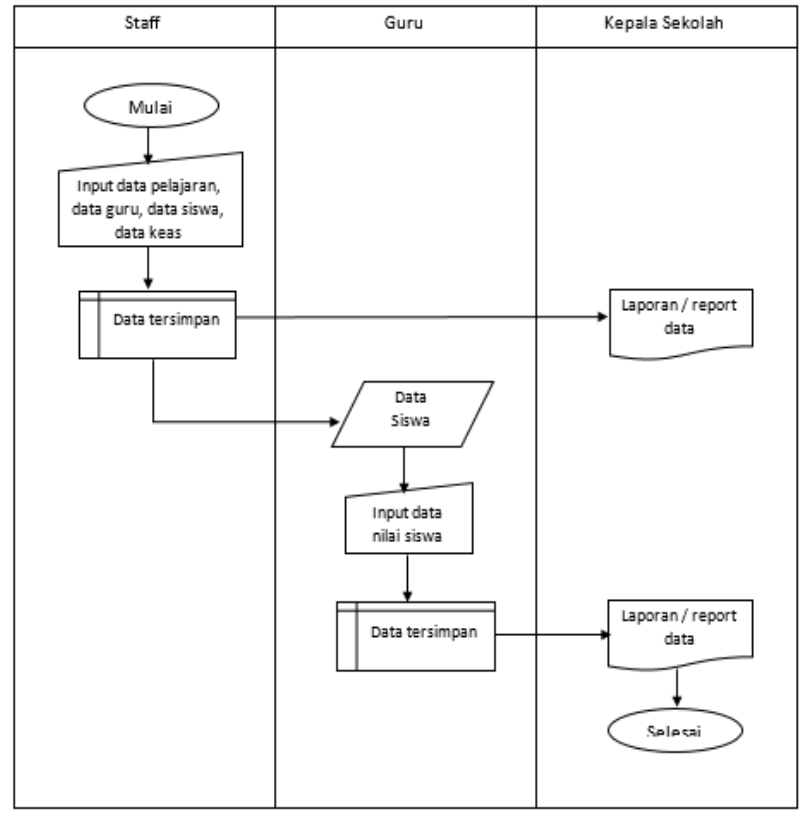

Fig 1. The system flowmap is running

B. Analysis of the proposed system

The proposed system analysis is based on the website using the PHP programming language and using the MYSQL database. The use of the website can streamline time and make it easier for staff and teacher sections in processing data such as student data, teacher data, class schedule data, and grade data. Besides the school principal can easily access information from the website. Here is the proposed academic information system flow map:

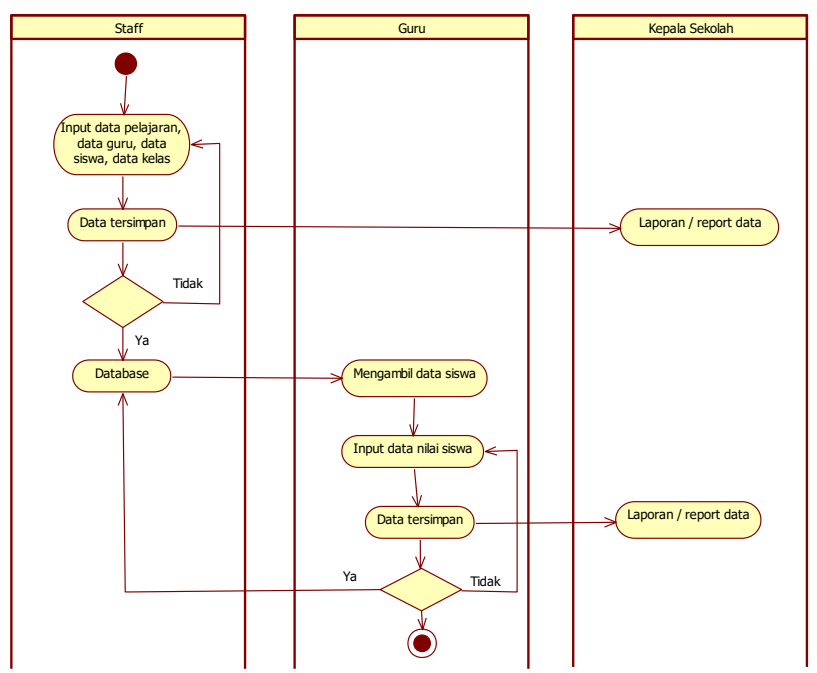

Fig 2. Activity diagram of the proposed system

\section{Class diagram}

Class diagrams are used fatherly to illustrate the relationship between classes of a system. The following class diagram of the academic information system application.

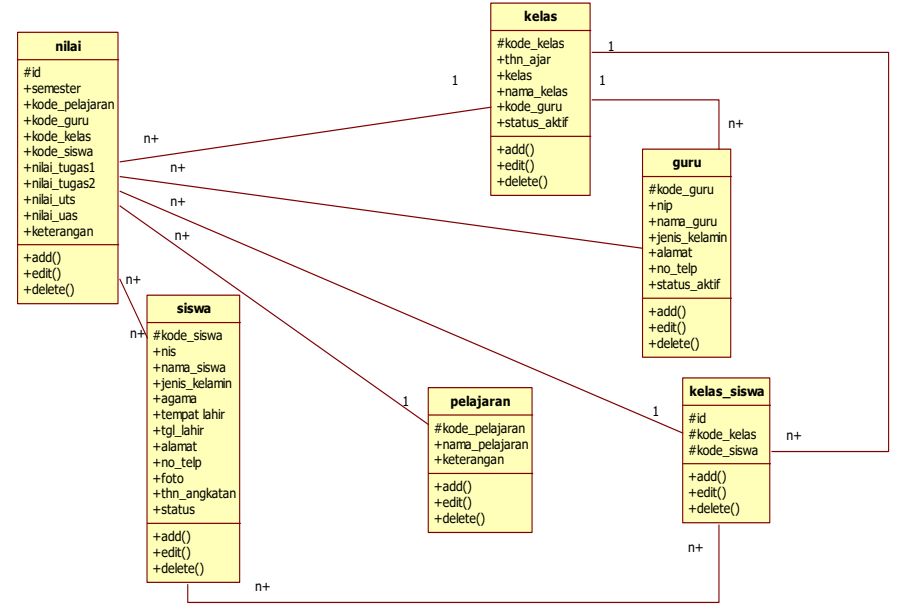

Fig 3. Class diagram academic information system

D. Application Testing

At the application testing stage in this thesis is done using the black-box testing method, wherein this testing is carried out functional testing from the user's side.

E. Maintenance

Maintenance is carried out to maintain applications that have been implemented. This implementation is planned periodically. It is expected that the application can continue to run also can be known as the potential for unwanted things such as data theft.

\section{CONCLUSION}

The conclusion that can be drawn from the making of Information Systems academics at Purwasari one junior high school are as follows; This web-based academic information system can assist in the processing and archiving of academic data, namely; student data, teacher data, lesson data, class data, lesson schedules, and student grades. staff and teacher data management, student subject management reports, and student grade management reports quickly.

\section{REFERENCES}

[1] W. Hidayat, "Perancangan Media Video Desain Interior Sebagai Salah Satu Penunjang Promosi Dan Informasi Di Pt . Wans Desain Group," Cerita, Vol. 2, No. 1, Pp. 35-49, 2016.

[2] P. Kristanto, "Ekologi Industri," J. Chem. Inf. Model., Vol. 5, No. 2011, Pp. 1689-1699, 2013.

[3] H. Abdurahman And A. R. Riswaya, "Aplikasi Pinjaman Pembayaran Secara Kredit Pada Bank Yudha Bhakti," J. Comput. Bisnis, Vol. 8, No. 2, Pp. 61-69, 2014.

[4] D. M. Farid Suryandani, Basori, "Pengembangan Sistem Informasi Akademik Berbasis Web Sebagai Sistem Pengolahan Nilai Siswa Di Smk Negeri 1 Kudus," J. Chem. Inf. Model., Vol. 53, No. 9, Pp. 1689-1699, 2013.

[5] S. K. Dewi Anggun Kumalasari, Hasan Nur Faozi, "Perancangan Sistem Informasi Administrasi 
Keuangan Sekolah Berbasis Multiuser Pada Madrasah Tsanawiyahal Uswah Bergas," 입법학연구, Vol. 제13집 1호, No. May, Pp. 31-48, 2016.

[6] A. D. Anggi S, Eko R, "Perancangan Sistem Informasi Berbasis Website Subsistem Guru Di
Sekolah Pesantern Islam 99 Rancabango," SttGarut, 2015.

[7] A. Suhadya, "Perancangan Website Sebagai Media Promosi," J. Inform. Pelita Nusant., Vol. 3, No. 1, Pp. 82-86, 2013. 